\title{
Soil Organic Matter, Mitigation of and Adaptation to Climate Change in Cocoa-Based Agroforestry Systems
}

\author{
Sikstus Gusli ${ }^{1,2, *(1)}$, Sri Sumeni ${ }^{1}$, Riyami Sabodin ${ }^{1}$, Ikram Hadi Muqfi ${ }^{1}$, Mustakim Nur ${ }^{1}$, \\ Kurniatun Hairiah ${ }^{3}$, Daniel Useng ${ }^{2,4}$ and Meine van Noordwijk ${ }^{5,6}$ (D) \\ 1 Department of Soil Science, Faculty of Agriculture, Hasanuddin University, Makassar 9245, Indonesia; \\ srisumeni31@gmail.com (S.S.); riyamial@gmail.com (R.S.); ikramhadimuqfi@gmail.com (I.H.M.); \\ takimkure.20@gmail.com (M.N.) \\ 2 Natural Resource Research and Development Center, Hasanuddin University, Makassar 9245, Indonesia; \\ daniel.useng@agri.unhas.ac.id \\ 3 Department of Soil Science, Faculty of Agriculture, Brawijaya University, Malang 65415, Indonesia; \\ kurniatun_h@ub.ac.id \\ 4 Department of Agricultural Engineering, Hasanuddin University, Makassar 9245, Indonesia \\ 5 World Agroforestry Centre (ICRAF), Bogor 16001, Indonesia; m.vannoordwijk@cgiar.org \\ 6 Plant Production Systems, Wageningen University, 6708 PB Wageningen, The Netherlands \\ * Correspondence: sikstusgusli@unhas.ac.id
}

Received: 11 August 2020; Accepted: 10 September 2020; Published: 14 September 2020

check for updates

\begin{abstract}
Belowground roles of agroforestry in climate change mitigation (C storage) and adaptation (reduced vulnerability to drought) are less obvious than easy-to-measure aspects aboveground. Documentation on these roles is lacking. We quantified the organic $C$ concentration $\left(\mathrm{C}_{\text {org }}\right)$ and soil physical properties in a mountainous landscape in Sulawesi (Indonesia) for five land cover types: secondary forest (SF), multistrata cocoa-based agroforestry (CAF) aged 4-5 years (CAF4), 10-12 years (CAF10), 17-34 years (CAF17), and multistrata (mixed fruit and timber) agroforest (MAF45) aged 45-68 years. With four replicate plots per cover type, we measured five pools of C-stock according to IPCC guidelines, soil bulk density (BD), macro porosity (MP), hydraulic conductivity $\left(\mathrm{K}_{\mathrm{s}}\right)$, and available water capacity of the soil (AWC). The highest C-stock, in SF, was around $320 \mathrm{Mg} \mathrm{ha}^{-1}$, the lowest, $74 \mathrm{Mg} \mathrm{ha}^{-1}$, was in CAF4, with the older agroforestry systems being intermediate with 120 to $150 \mathrm{Mg} \mathrm{ha}^{-1}$. Soil compaction after forest conversion led to increased BD and reduced MP, $\mathrm{K}_{\mathrm{s}}$, and AWC. Older agroforestry partly recovered buffering: AWC per $\mathrm{m}$ of rooted soil profile increased by $5.7 \mathrm{~mm}$ per unit $\left(\mathrm{g} \mathrm{kg}^{-1}\right)$ increase of $C_{\text {org }}$. The restored AWC can support about a week's worth of evapotranspiration without rain, assisting in climate change adaptation.
\end{abstract}

Keywords: cocoa agroforestry; climate adaptation; soil restoration; soil organic carbon; soil macro-porosity; soil water availability; inceptisols

\section{Introduction}

Agroforestry, integrating trees in farms, implies reforestation (or at least re-treeing) within an agricultural framework of land tenure and practice [1,2]. Growing cocoa between various other trees as shade or companion trees to increase overall income from farming is one of the many forms of agroforestry [3]. Agroforestry can connect the climate change (CC) policy imperatives on mitigation - reducing net emissions of greenhouse gasses - and adaptation: reducing human vulnerability to increased climate variability and global warming trends [4,5]. These connections are made aboveground as increased tree cover in agricultural landscapes stores carbon [6,7] and modifies microclimates [8]. 
Moreover, belowground soil carbon storage will increase in agroforestry [9] while the soil water buffer function can be enhanced [10]. Yet, the belowground effects are slower (both in their degradation and their restoration phases [11]) and less visible than those aboveground and need to be teased out from a substantial background variability of soil diversity $[12,13]$. In accordance with the 'cascade' perspective on ecological structure and function, which shapes ecosystem services that represent the benefits people derive from functioning (agro)ecosystems as a basis for valuation and explicit decision making (Figure 1A, [14]), the chain of required evidence for belowground relevance of agroforestry for $\mathrm{CC}$ adaptation can be considered in three steps (Figure 1B):

A. Effects of trees as part of land cover change on soil organic matter (and soil carbon storage),

B. Relations between soil organic matter and soil physical properties relevant to crop vulnerability to climate variability, and

C. Deliberate farmer use of trees to reduce their own vulnerability (the adaptation line), potentially supported by global climate policies (if incentives will reach the farmer, then the dotted line).

\section{A. Generic}

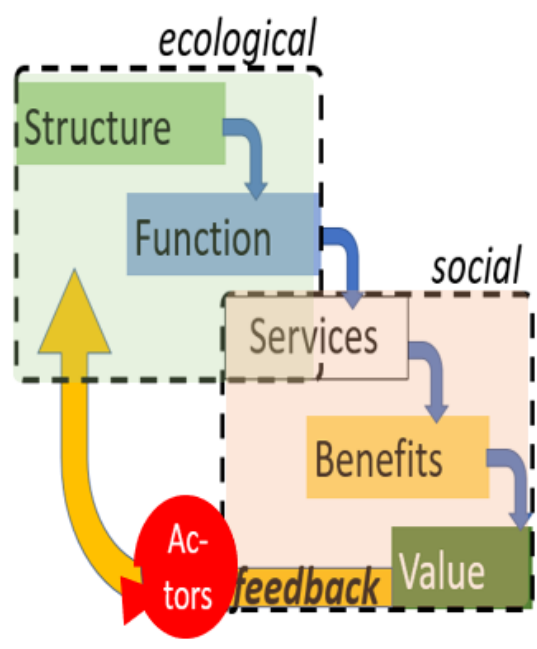

\section{B. Specific}

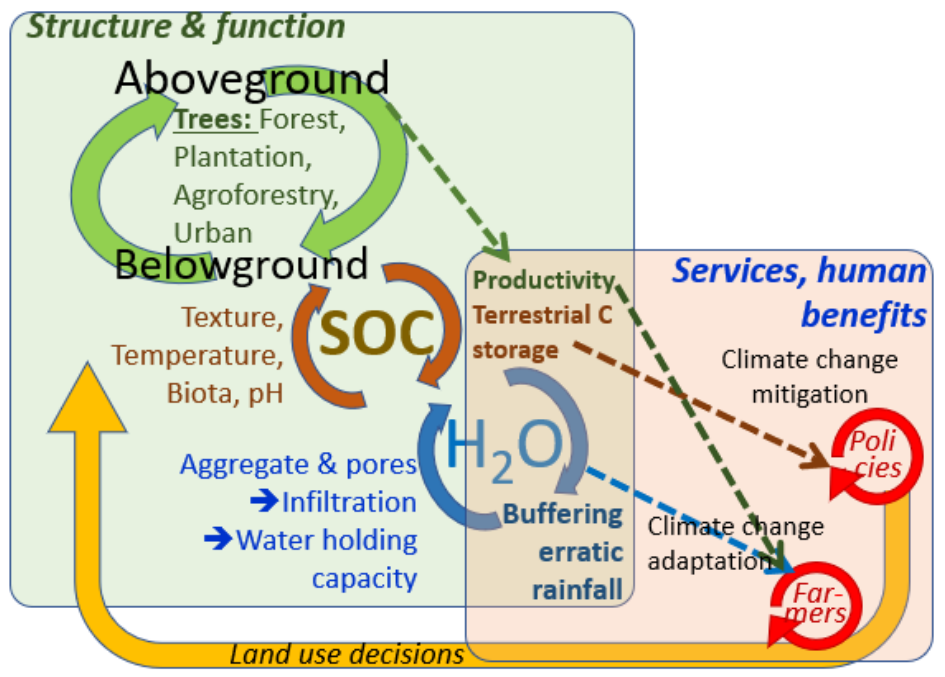

Figure 1. (A) Cascade representation of ecosystem structure and function, interacting with social systems via 'ecosystem services' [14]; (B) Relationship between the agroecosystem structure (observable), function (inferred), and human benefits (policy focus) in relation to the growth cycle of trees, the formation, and the decay of soil organic carbon (SOC), climate change, and the water $\left(\mathrm{H}_{2} \mathrm{O}\right)$ cycle.

Soil organic matter needs to be understood in its central role in belowground C storage (mitigation) and its influence on soil water balance and hence on climate vulnerability (adaptation). Obtaining a full account of all inputs, both aboveground and belowground, and their associated rates of turnover and interaction with mineral soil particles in shaping soil physical properties is no simple task for even relatively simple forms of cocoa agroforestry. Stock changes over time can provide an indication of the net effects of interacting processes, as both plants [15] and farmers adapt to climate change [16]. Co-adaptation of people and trees is needed for resilience to climate change in the medium term [17].

Cocoa (Theobroma cacao L.) is grown across the humid tropics and is a major driver of tropical forest transitions [18]. Whether or not cocoa agroforestry increases or reduces vulnerability to uncertain rainfall is contested [19] and may depend on the tree species used, the soil, and climatic conditions. Within cocoa production, comparisons between more open and more shaded systems have revealed ecological, social, and economic variables [20-22], with farmer choices depending on location, markets, and evolving knowhow. According to global agriculture database data [23], Indonesia still is the third-largest global cocoa producer, while international cocoa organization data [24] suggests that it is 
the fifth-largest global cocoa producer. Indonesian smallholder cocoa production confronts multiple challenges on how to increase productivity as well as smallholder's prosperity, reduce pressure on forest conversion, and be adaptive and resilient to climate change [25]. Nearly a million hectares of forest was converted to cocoa farmland in Indonesia, especially in the island of Sulawesi [26], most notably in the 1980s [27] during the period of cocoa booming. Such conversion was intended to increase smallholder income, however it led to declining soil health by reducing soil biodiversity and the soil microbiome [28,29], compacting soils, reducing infiltration and soil water storage [30], depleting soil fertility [31], and reducing environmental services [32,33] such as carbon storage [34,35].

In the last twenty years, cocoa farmland management in Sulawesi has been dynamic, very much influenced by field experience and information gathered by returning migrant farmers from Malaysia [24]. In the early 1970s to 1980s, cocoa was grown as mixed cropping with food crops (mostly in flat land); much of the land was converted to monoculture (full sun) cocoa in the 1990s. The monoculture practice expanded rapidly including on sloping lands, in response to the information from other places that this system produces higher yields than cocoa grown under shade, especially in the short term [36]. Yet, farmers eventually learnt that, in the longer term, cocoa grown as a single crop suffered from pests and diseases, including the damaging vascular strike dieback, which can kill cocoa trees under heavy infestation [37]. Farmers also claimed that monoculture cocoa suffers more from extreme weather conditions (heavy rain or long dry periods), while monoculture cocoa only allows farmers to earn money in the months during the harvest periods. Learning from this experience, many cocoa farmers at present also grow other plants between cocoa trees, including horticultural crops, as shade trees for the cocoa and as extra income sources for the farmers. While the structure and functions of cocoa-based agroforestry practices are easily observed aboveground, their belowground roles are less obvious and remain poorly documented, including carbon storage dynamics in terms of the various agroforestry types and ages and its effects on climate change mitigation and adaptation, as well as changes of soil properties affecting vulnerability to drought.

In this study, we explored the relationships between A) Agroforestry land cover, aboveground and belowground carbon stocks, and B) Soil carbon and soil physical conditions, as steps towards assessing contributions to CC adaptation have occurred in the context of southern Sulawesi where farmers in the Polewali-Mandar District grow cocoa with three major systems: monoculture with minimum shade trees and both simple- and complex- (multilayers) agroforestry systems of varying ages. We tested the hypothesis that in cacao production systems, the farmer-level benefits from agroforestry through increased water storage, contributing to climate change adaptation, are parallel to global benefits of climate change mitigation through increased $C$ storage. If such a synergy exists between local and global climate change agendas, then it is easier for climate policy to provide appropriate incentives.

\section{Methods}

\subsection{Sampling Sites}

We conducted the study in a mountainous landscape of Sulawesi, Indonesia with sample sites ranging from 93 to $575 \mathrm{~m}$ above sea level (Figure 2), on five land cover types (all were directly converted from primary forest according to local land use history) consisting of young smallholder cocoa agroforestry (CAF4, 4 to 5 years old), medium-aged smallholder cocoa agroforestry (CAF10, 10 to 12 years old), old smallholder cocoa agroforestry (CAF17, 17 to 34 years), multistrata agroforest (MAF45, 45 to 68 years after forest conversion) owned by smallholders, and remnant secondary tropical forest (SF). Information on the year planted or converted from forest was obtained directly from the farm owners who lived on and managed the farms. The sites of these agroforestry systems (CAF4, CAF10, CAF1,7 and MAF45) are scattered at elevations between 100 to $300 \mathrm{~m}$ above the sea level, with an 8 to $30 \%$ slope. The three sites of SFs are at $>400 \mathrm{~m}$ above the sea level and 30 to over $40 \%$ slope. The average annual rainfall of the area is $2113 \mathrm{~mm}$. 


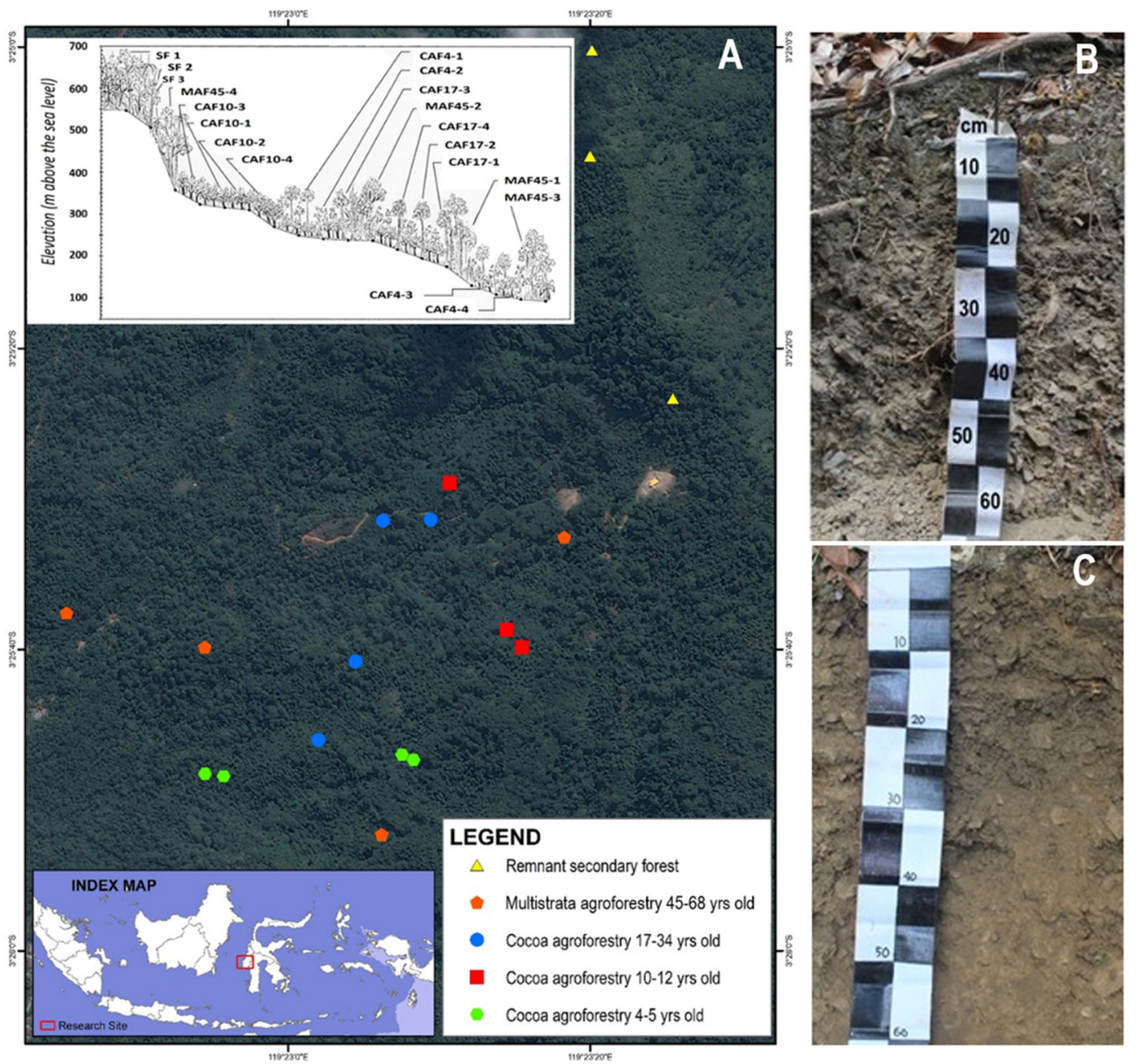

Figure 2. (A) The site distribution (satellite image) of remnant secondary forest (SF), multistrata agroforest that is 45-68 years old (MAF45), cocoa agroforestry that is 17-34 years old (CAF17), cocoa agroforestry that is $10-12$ years old (CAF10), and cocoa agroforestry that is $4-5$ years old (CAF4). The topo-sequence positions are shown to indicate slopes and elevations of the systems. The cocoa agroforestry sites are scattered randomly within 100 to $300 \mathrm{~m}$ above sea level (a.s.l.), generally 8 to $30 \%$ in slope, but the SFs are at $>400 \mathrm{~m}$ a.s.l. with a slope from 30 to over $40 \%$. CAF (of all ages) refers to cocoa farming practices where at least five other tree species (with shade and/or direct use functions) are used alongside cocoa trees as the main crop. MAF denotes a farming practice of multiple tree species, dominated by horticultural trees, cocoa is not the main crop. (B) A typical (common) soil profile of the study area for all land uses showing abundance of rock fragments, especially below a 20 or $30 \mathrm{~cm}$ depth. (C) A profile of less stony soil (uncommon).

The plots differed in vegetation structure and stratification, but all had permanent litter layers (Figure 3). We did not find remnants of natural (primary) forest in the neighborhood. The surface soil of all land-uses was well covered by mulch (litter layer). For each land-cover type, we selected four sites (replicates), managed by separate households; however, due to forest area limitations, only three sites were sampled in SF, in a single landscape location. Hence, across these five land-uses we evaluated 19 plots. 


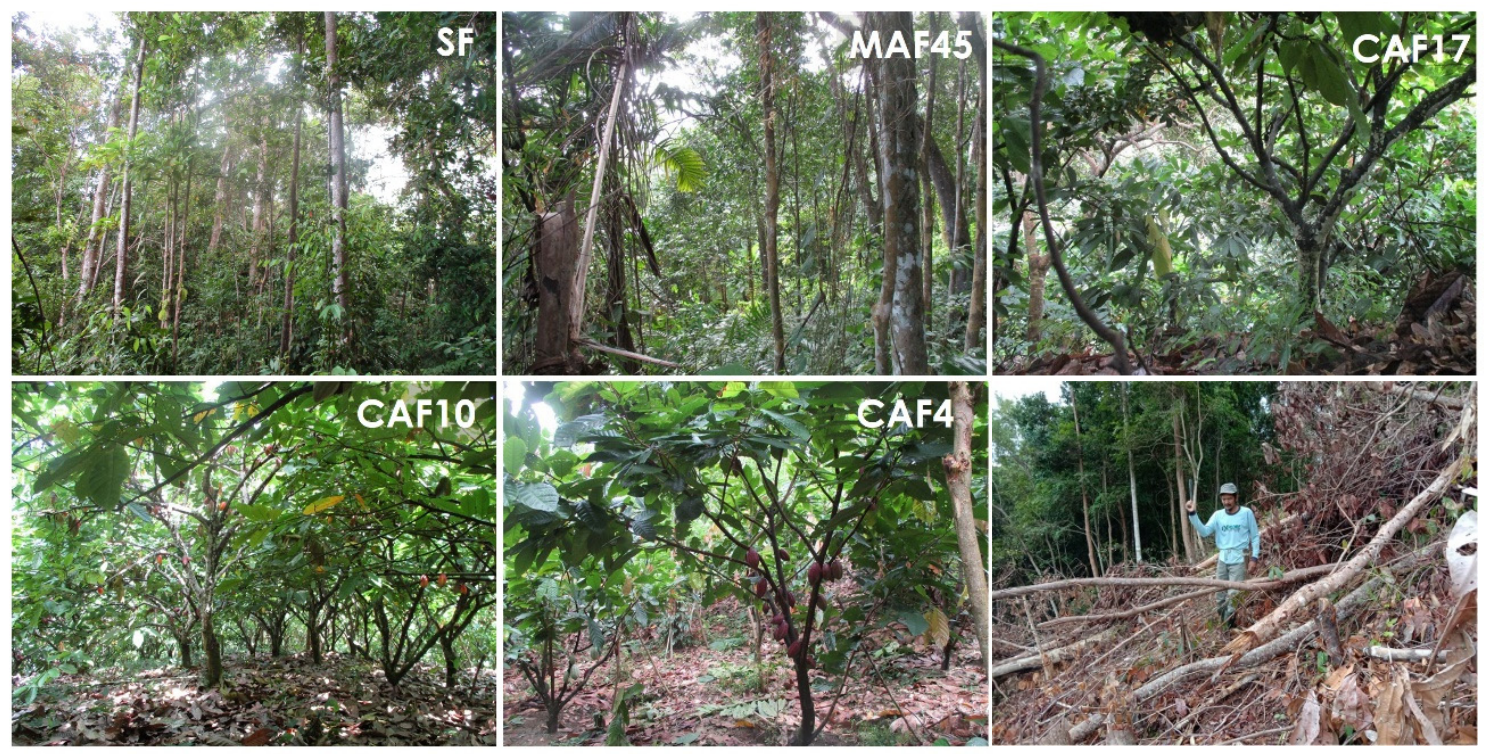

Figure 3. Typical look of the five land-use systems, namely remnant secondary forest (SF), multistrata agroforest that is 45-68 years old (MAF45), cocoa agroforestry that is 17-34 years old (CAF17), cocoa agroforestry that is 10-12 years old (CAF10), and cocoa agroforestry that is $4-5$ years old (CAF4). Bottom right corner: SF being land-cleared using a chain saw and machete operated by the owner for a new mixed cocoa agroforestry (CAF), without burning.

At the soil surface, the rock fragments covered 10 to 20 percent of the soil surface, but beyond a $30 \mathrm{~cm}$ depth, rocks occupied nearly half of the soil volume. Soils in each site varied from coarseto medium-textures (sandy loam, sandy clay loam, and loam), with an increase of clay content as the depth increases. To minimize confounding effects of soil texture and elevation on C-organic concentrations, we used reference values based on a pedotransfer function [9] as a basis of comparisons. The pedotransfer function we used accounts for texture (microaggregate $C$ protection) and elevation (as proxy for temperature) effects on expected C-organic concentrations (with coefficients for silt, clay, $\mathrm{pH}$, elevation, and specific soil types) [13]; this was reconfirmed in recent analysis [9], with an additional correction for sampling depths. The $C_{\text {ref }}$ values can help in judging the validity of the 'chronosequence' interpretation of observed differences between land uses as being 'caused' by land use in an otherwise homogeneous background situation. Variations in texture (Table 1) stayed within the 'Loam' and 'Sandy Loam' classes, with the lowest $C_{\text {ref }}$ value $9 \%$ below and the highest $14 \%$ above the mean for layer-specific results. This can be compared to $\mathrm{C}_{\text {org }}$ with a lowest value $25 \%$ below and a highest one $59 \%$ above the average. Variation in texture can thus not be ignored in the interpretation of plot-level $C_{\text {org }}$ results in relation to land use. For part of the analysis, we relied on the $C_{\text {org }} / C_{\text {ref }}$ ratio as a potentially more sensitive indicator of land use effects [9], as it has considered that the 'chronosequence' interpretation assumes that there is no variation in texture. 
Table 1. Particle-size distribution (USDA classification), $\mathrm{pH}$ and derived reference organic carbon concentration (C-ref, responding to texture and $\mathrm{pH}$ ) of the soil to a depth of $30 \mathrm{~cm}$, as test of homogeneity of the sample sites used for the five land uses; values in brackets are standard errors of the means of four measurements; for C-ref and measured C-org, the values are also provided after normalization on the mean across land uses per soil layer.

\begin{tabular}{|c|c|c|c|c|c|c|c|c|c|c|}
\hline \multirow{2}{*}{$\begin{array}{l}\text { Land } \\
\text { Use * }\end{array}$} & \multirow{2}{*}{$\begin{array}{c}\text { Soil } \\
\text { Depth } \\
\text { (cm) }\end{array}$} & \multicolumn{3}{|c|}{$\begin{array}{c}\text { Particle-Size } \\
\text { Distribution }\left(\mathrm{g} \mathrm{kg}^{-1}\right)\end{array}$} & \multirow{2}{*}{$\begin{array}{l}\text { Soil } \\
\text { Texture }\end{array}$} & \multirow{2}{*}{$\begin{array}{c}\mathrm{pH} \\
(\mathbf{1 N} \\
\mathrm{KCl})\end{array}$} & \multirow{2}{*}{$\begin{array}{l}\text { C-Ref } \\
\left(\mathrm{g} \mathrm{kg}^{-1}\right)\end{array}$} & \multirow{2}{*}{$\begin{array}{l}\text { Normalized } \\
\text { C-Ref Per } \\
\text { Layer }\end{array}$} & \multirow{2}{*}{$\begin{array}{c}\text { C-org } \\
\left(\mathrm{g} \mathrm{kg}^{-1}\right)\end{array}$} & \multirow{2}{*}{$\begin{array}{c}\text { Normalized } \\
\text { C-Org Per } \\
\text { Layer }\end{array}$} \\
\hline & & Clay & Silt & Sand & & & & & & \\
\hline \multirow[t]{3}{*}{ SF } & $0-10$ & $\begin{array}{l}128 \\
(49)\end{array}$ & $\begin{array}{l}176 \\
(25)\end{array}$ & $\begin{array}{l}674 \\
(54)\end{array}$ & $\begin{array}{l}\text { Sandy } \\
\text { loam }\end{array}$ & $\begin{array}{l}3.8 \\
(0.2)\end{array}$ & $22.1(1.5)$ & 1.13 & $21.8(0.3)$ & 1.32 \\
\hline & $10-20$ & $\begin{array}{l}192 \\
(48)\end{array}$ & $\begin{array}{l}175 \\
(41)\end{array}$ & $\begin{array}{l}610 \\
(67)\end{array}$ & $\begin{array}{l}\text { Sandy } \\
\text { loam }\end{array}$ & $\begin{array}{l}3.6 \\
(0.3)\end{array}$ & $15.3(1.3)$ & 1.14 & $21.6(0.5)$ & 1.59 \\
\hline & $20-30$ & $\begin{array}{l}118 \\
(52)\end{array}$ & $\begin{array}{l}294 \\
(14)\end{array}$ & $\begin{array}{l}571 \\
(65)\end{array}$ & $\begin{array}{l}\text { Sandy } \\
\text { loam }\end{array}$ & $\begin{array}{l}3.8 \\
(0.5)\end{array}$ & $13.0(1.5)$ & 1.09 & $17.7(3.2)$ & 1.47 \\
\hline \multirow[t]{3}{*}{ CAF4 } & $0-10$ & $\begin{array}{c}82 \\
(13)\end{array}$ & $\begin{array}{l}309 \\
(52)\end{array}$ & $\begin{array}{l}606 \\
(42)\end{array}$ & $\begin{array}{l}\text { Sandy } \\
\text { loam }\end{array}$ & $\begin{array}{c}4.4 \\
(0.3)\end{array}$ & $17.0(1.0)$ & 0.87 & $16.2(0.6)$ & 0.98 \\
\hline & $10-20$ & $\begin{array}{c}96 \\
(46)\end{array}$ & $\begin{array}{l}323 \\
(33)\end{array}$ & $\begin{array}{l}567 \\
(32)\end{array}$ & $\begin{array}{l}\text { Sandy } \\
\text { loam }\end{array}$ & $\begin{array}{c}4.1 \\
(0.3)\end{array}$ & $12.4(0.7)$ & 0.92 & $12.4(1.3)$ & 0.91 \\
\hline & $20-30$ & $\begin{array}{l}86 \\
(22)\end{array}$ & $\begin{array}{l}375 \\
(18)\end{array}$ & $\begin{array}{l}527 \\
(24)\end{array}$ & Loam & $\begin{array}{c}3.7 \\
(0.3)\end{array}$ & $11.4(0.5)$ & 0.96 & $10.4(1.5)$ & 0.87 \\
\hline \multirow[t]{3}{*}{ CAF10 } & $0-10$ & $\begin{array}{c}94 \\
(19)\end{array}$ & $\begin{array}{l}288 \\
(57)\end{array}$ & $\begin{array}{l}602 \\
(43)\end{array}$ & $\begin{array}{l}\text { Sandy } \\
\text { loam }\end{array}$ & $\begin{array}{c}4.1 \\
(0.3)\end{array}$ & $19.8(1.1)$ & 1.01 & $15.1(1.2)$ & 0.92 \\
\hline & $10-20$ & $\begin{array}{c}80 \\
(25)\end{array}$ & $\begin{array}{l}325 \\
(27)\end{array}$ & $\begin{array}{l}578 \\
(39)\end{array}$ & $\begin{array}{l}\text { Sandy } \\
\text { loam }\end{array}$ & $\begin{array}{c}3.9 \\
(0.2)\end{array}$ & $13.2(0.8)$ & 0.98 & $11.4(1.3)$ & 0.84 \\
\hline & $20-30$ & $\begin{array}{c}67 \\
(19)\end{array}$ & $\begin{array}{l}390 \\
(37)\end{array}$ & $\begin{array}{l}530 \\
(34)\end{array}$ & Loam & $\begin{array}{c}3.8 \\
(0.2)\end{array}$ & $11.8(0.4)$ & 0.99 & $10.4(1.4)$ & 0.87 \\
\hline \multirow[t]{3}{*}{ CAF17 } & $0-10$ & $\begin{array}{c}93 \\
(17)\end{array}$ & $\begin{array}{l}341 \\
(43)\end{array}$ & $\begin{array}{l}554 \\
(47)\end{array}$ & $\begin{array}{l}\text { Sandy } \\
\text { loam }\end{array}$ & $\begin{array}{c}3.9 \\
(0.4)\end{array}$ & 20.7 (1.6) & 1.06 & $13.5(1.1)$ & 0.82 \\
\hline & $10-20$ & $\begin{array}{l}138 \\
(42)\end{array}$ & $\begin{array}{l}319 \\
(26)\end{array}$ & $\begin{array}{l}525 \\
(28)\end{array}$ & Loam & $\begin{array}{c}3.4 \\
(0.4)\end{array}$ & $14.2(0.7)$ & 1.05 & $10.2(0.3)$ & 0.75 \\
\hline & $20-30$ & $\begin{array}{l}138 \\
(31)\end{array}$ & $\begin{array}{l}347 \\
(44)\end{array}$ & $\begin{array}{l}504 \\
(39)\end{array}$ & Loam & $\begin{array}{c}3.5 \\
(0.4)\end{array}$ & $12.4(0.9)$ & 1.04 & $10.0(0.6)$ & 0.83 \\
\hline \multirow[t]{3}{*}{ MAF45 } & $0-10$ & $\begin{array}{l}119 \\
(33)\end{array}$ & $\begin{array}{l}254 \\
(28)\end{array}$ & $\begin{array}{l}607 \\
(36)\end{array}$ & $\begin{array}{l}\text { Sandy } \\
\text { loam }\end{array}$ & $\begin{array}{c}4.3 \\
(0.4)\end{array}$ & $18.5(1.1)$ & 0.94 & $15.7(2.0)$ & 0.95 \\
\hline & $10-20$ & $\begin{array}{l}131 \\
(45)\end{array}$ & $\begin{array}{l}267 \\
(15)\end{array}$ & $\begin{array}{l}583 \\
(32)\end{array}$ & $\begin{array}{l}\text { Sandy } \\
\text { loam }\end{array}$ & $\begin{array}{c}4.2 \\
(0.3)\end{array}$ & $12.2(0.5)$ & 0.91 & $12.2(2.2)$ & 0.90 \\
\hline & $20-30$ & $\begin{array}{l}124 \\
(50)\end{array}$ & $\begin{array}{l}313 \\
(45)\end{array}$ & $\begin{array}{l}540 \\
(32)\end{array}$ & $\begin{array}{l}\text { Sandy } \\
\text { loam }\end{array}$ & $\begin{array}{c}4.1 \\
(0.3)\end{array}$ & $10.8(0.4)$ & 0.91 & 11.6 (2.6) & 0.97 \\
\hline
\end{tabular}

${ }^{*} \mathrm{SF}=$ secondary forest, $\mathrm{CAF}=$ cocoa agroforestry, MAF-multistrata agroforest, with years since the plot establishment indicated.

\subsection{Land Cover}

Beyond cocoa, a range of other fruit tree species was part of local agroforestry systems, including langsat (Lansium domesticum Corr.), durian (Durio zibethinus Murr.), rambutan (Nephelium lappaceum L.), jackfruit (Artocarpus heterophyllus Lam.), cempedak (Artocarpus integer (Thunb.) Merr.), star fruit (Averrhoa carambola L.), and candlenut trees (Aleurites moluccanus L.). Timber trees include white teak (Gmelina arborea Roxb.), sandalwood (Santalum album L.), cananga (Cananga odorata (Lam.) Hook.), and bitti (Vitex cofassus Reinw.). Various bamboo species (Bambusoideae sp.) are also a source of construction material, with young shoots as a food source. Bananas (Musa spp.), papaya (Carica papaya L.), sugar palm (Arenga pinnata Merr.), and chili (Capsicum annuum L.) are present as readily marketable food sources. As the 'mother of cocoa', gliricidia (Gliricidia sepium Jack.) was common as nitrogen-fixing shade trees, as was leucaena (Leucaena leucocephala (Lam.) de Wit). Most of these trees were planted, although some sufficiently naturalized to spread spontaneously. Farmer management is based on selective retention of trees with use value, similar to what was documented for Southeast Sulawesi [38].

The vegetation found in the remnant forest (SF) was dominated by Castanopsis acuminatissima (Blume) A., Symplocos polyandra (Blanco) Brand., rattan (Calamus deerratus G.Mann \& H.Wendl.), forest/wild pandan (Pandanus amaryllifolius Roxb.), bamboo (Bambusa spp), and some hardwood tree species (locally named dao, bubun, nato) including kluwak (Pangium edule Reinw.), trees that are locally 
called forest teak, gattungan, ebony (Diospyros celebica Bakh.), trees that are locally named belating, candlenut, coffee (Coffea sp), cananga trees, and various shrubs. All these species are part of Sulawesi's native flora.

\subsection{C-stock Measurements}

Within the selected sites, based on the field vegetation conditions that represent the land-use type, we set up four C-stock observation plots according to the RaCSA (Rapid Carbon Stock Appraisal) procedure outlined by [39] and used in a cocoa landscape context by [38]. While other C sampling protocols prefer circular plots to maximize plot homogeneity, the basic plot size in the RACSA protocol is a transect-like $40 \mathrm{~m}$ by $5 \mathrm{~m}$ to include variation within a plot; some adjustments to plot dimensions were made where $40 \mathrm{~m} \times 5 \mathrm{~m}$ was not possible. Where we found trees with DBH greater than $30 \mathrm{~cm}$ as in the SF, plot size was expanded for such trees to $100 \mathrm{~m}$ by $20 \mathrm{~m}$, as they tend to occur at lower frequency but have considerable impact on total biomass estimates [39]. On the other hand, in cocoa farms (CAF17, CAF4 and CAF10) with regular cocoa planting distance of $3 \mathrm{~m} \times 4 \mathrm{~m}$, the plot size was increased to be $20 \mathrm{~m}$ by $20 \mathrm{~m}$. In these plots, we measured all trees with a stem diameter at breast height $(\mathrm{DBH})$ of 5 to $30 \mathrm{~cm}$. In every basic plot, we randomly selected six sub-plots of $50 \mathrm{~cm}$ by $50 \mathrm{~cm}$, where we measured C-stock of understory (destructing sampling), non-woody necromass, and soil organic carbon (depth of 0-30 cm). For woody necromass, where present, we followed the protocol of [39].

\subsection{Aboveground and Belowground Biomass}

Tree biomass was estimated allometrically from the stem diameters, using allometric equations for Aboveground biomass (AGB in $\mathrm{kg}$ per tree) (Table 2), on the basis of stem diameter (D, in $\mathrm{cm}$ ) at $1.3 \mathrm{~m}$ above the soil surface, with wood density $\rho$ (in $\mathrm{g} \mathrm{cm}^{-3}$, obtained from the World Agroforestry database [http://db.worldagroforestry.org/wd, April 2014]. Wood density is used in allometric equations that are derived across many different tree species; as these equations are calibrated on a wider range of tree diameter data, equations that deviate from the simple power laws used for the other equations account for a larger share of the variation in the calibration datasets [40].

Table 2. Allometric equations used for aboveground biomass ( $\left.\mathrm{AGB}_{\mathrm{est}}\right)$ based on stem diameter $\mathrm{D}$.

\begin{tabular}{ccc}
\hline Component & Allometric Equation for AGB est & Reference \\
\hline Cocoa & $0.1208 \mathrm{D}^{1.98}$ & {$[41]$} \\
Generic trees, humid tropics & $\rho \times \exp (-1.499+2.148 \ln (\mathrm{D})+$ & {$[40]$} \\
(rainfall 1500-4000 $\left.\mathrm{mm} \mathrm{yr}^{-1}\right)$ & $\left.0.207(\ln (\mathrm{D}))^{2}-0.0281(\ln (\mathrm{D}))^{3}\right)$ & {$[42]$} \\
Banana & $0.030 \mathrm{D}^{2.13}$ & {$[43]$} \\
Palm & $0.118 \mathrm{D}^{2.53}$ & \\
\hline
\end{tabular}

Tree basal area $\left(\mathrm{m}^{2} \mathrm{ha}^{-1}\right)$ was calculated by summing their cross-sectional area $\pi \mathrm{D}^{2} / 4$ of all sampled trees and scaling up from the sampled area, while converting from $\mathrm{cm}^{2}$ to $\mathrm{m}^{2}$. Formulas used to calculate woody necromass depend on the wood decomposition stage [39]. The decomposition stage was assessed in the field based on ease of inserting a metal rod into woody necromass. On recent tree falls, where the decomposition stage was low, the equations of Table 2 were used. However, where the necromass was highly decomposed, Equation (1) was used, and wood density was assumed to be $0.4 \mathrm{~g} \mathrm{~cm}^{-3}$ [39]:

$$
\mathrm{N}_{\mathrm{D}}=\rho \mathrm{H} \mathrm{D}^{2} / 40
$$

where $\mathrm{N}_{\mathrm{D}}$ is dry necromass $(\mathrm{kg})$.

Measurement of understory biomass was done on six randomly selected quadrants of $50 \mathrm{~cm}$ by $50 \mathrm{~cm}$ in every land-use. Understory vegetation in the quadrants was collected, weighed, then taken to laboratory for oven-drying at $80{ }^{\circ} \mathrm{C}$ for $48 \mathrm{~h}$. Due to massive and bulky understory biomass 
samples, approximately $300 \mathrm{~g}$ sub-samples were taken from the field samples for dry weights. If the samples were less than $300 \mathrm{~g}$, the whole biomass was oven-dried. The understory dry weight (UD) was calculated as the ratio of oven-dry weight to the sub-sample fresh weight multiplied by the total fresh weight of understory biomass sampled in the field. Understory dry biomass of each land-use is the average of the six replicates of the respective land-use. The litter collected was carefully cleaned to remove adhering soil particles, before being taken to a laboratory for oven-drying at $80{ }^{\circ} \mathrm{C}$, for $48 \mathrm{~h}$. Calculation of litter biomass follows the same procedure as that for understory biomass.

Belowground biomass was estimated from the aboveground-tree root biomass relationship. A default value of the canopy/root ratio of 4/1 for wet tropical forest trees was applied [44]. However, for cocoa trees, we estimated the value based on the $6.7 / 1$ ratio developed by [45].

\subsection{Soil Properties}

On 19 sub-plots (four sub-plots each in CAF4, CAF10, CAF17 and MAF45, and 3 sub-plots in SF) we collected 57 of both disturbed and undisturbed soil samples at 0-10, 10-20, and 20-30 cm depths. In each sub-plot, we collected about $1 \mathrm{~kg}$ of disturbed soil samples per layer, mixed composite from six random spots within the same sub-plot for the measurements of soil organic carbon (C-org), soil texture, and soil carbon pools. The undisturbed soil samples (also collected from three soil depths at six random spots in each sub-plot) were used for bulk density, saturated hydraulic conductivity, water retention, soil porosity, macro-porosity and aeration, available water capacity (AWC), and soil structural quality measurements. C-org was determined according to the Walkley and Black procedure outlined by [46]; bulk density was determined in each land use using six large $(20 \mathrm{~cm}$ long $\times 20 \mathrm{~cm}$ wide $\times 10 \mathrm{~cm}$ deep) core samples as well as six standard small $(70 \mathrm{~mm}$ inner diameter, $50 \mathrm{~mm}$ length) ring samplers according to [47]; soil texture was determined using the pipet method outlined by [48] saturated hydraulic conductivity was measured in a laboratory at a constant head [49] using undisturbed samples with six replicates for each form of land use. Using the same undisturbed samples for saturated hydraulic conductivity and water retention at 0 and $5 \mathrm{kPa}$, matric suctions were determined using a hanging water column system [50,51]. Soil porosity was calculated from bulk density, assuming a particle density of mineral soils of $2.65 \mathrm{Mg} \mathrm{m}^{-3}$ [52]. Macro-porosity (effective diameter $>60 \mu \mathrm{m}$ ) was calculated according to the soil pore (capillarity radius) -matric suction relationship formula [53] at $5 \mathrm{kPa}(0.50 \mathrm{~m})$. Available water capacity was calculated as the difference between water content at field capacity ( $-5 \mathrm{kPa}$ matric potential) and at the wilting point $(-1500 \mathrm{kPa})$, measured using a pressure chamber [54]. Soil carbon stocks were calculated from bulk density and C-org data [9], pH was measured in $1 \mathrm{~N} \mathrm{KCl.}$

\section{Results}

\subsection{Density and Basal Area}

Land occupancy by trees, expressed in terms of tree basal area, of secondary forest was the most common form of land use (over $\left.14 \mathrm{~m}^{2} \mathrm{ha}^{-1}\right)$; it was significantly reduced $(p<0.05)$ when land was converted to other land uses (Table 3). Ten-to-twelve years old cocoa agroforestry (CAF10) had the lowest tree occupancy (just over $5 \mathrm{~m}^{2} \mathrm{ha}^{-1}$ ), but its difference with younger cocoa agroforestry systems (CAF4) was not statistically significant. Generally, the basal area increased as the cocoa-based agroforestry system aged. 
Table 3. Tree basal area and plant density of remnant secondary forest (SF), multistrata agroforest that is 45-68 years old (MAF45), cocoa agroforestry that is 17-34 years old (CAF17), cocoa agroforestry that is 10-12 years old (CAF10), and cocoa agroforestry that is $4-5$ years old (CAF4). The high plant density for CAF4 was mainly due to a high population of cocoa and shade trees introduced into the system. Shade trees are trees mainly planted to provide shade for cocoa, but several types also fix atmospheric nitrogen and thus improve soil fertility.

\begin{tabular}{|c|c|c|c|c|c|}
\hline Type of Tree or Plant & SF & MAF45 & CAF17 & CAF10 & CAF4 \\
\hline Basal area & \multicolumn{5}{|c|}{$-\left(\mathrm{m}^{2} \mathrm{ha}^{-1}\right)$} \\
\hline Timber trees & 12.42 & 4.50 & 0.19 & 2.02 & \\
\hline Fruit trees & & 4.02 & 3.11 & 0.50 & 2.73 \\
\hline Cocoa & & 0.70 & 3.71 & 2.13 & 2.71 \\
\hline Shade trees & & & 2.88 & 0.76 & 1.75 \\
\hline Palms & & 0.90 & & & \\
\hline Other trees & 1.91 & 0.67 & & & 0.84 \\
\hline Total & $14.33^{a}$ & $10.78^{b}$ & $9.88^{b}$ & $5.41^{\mathrm{c}}$ & $8.04^{b c}$ \\
\hline Plant density & \multicolumn{5}{|c|}{$-\left(\right.$ trees ha $\left.{ }^{-1}\right)$} \\
\hline$\overline{\text { Timber trees }}$ & 498 & 79 & 5 & 5 & \\
\hline Fruit trees & & 251 & 64 & 28 & 175 \\
\hline Cocoa & & 44 & 263 & 188 & 650 \\
\hline Shade trees & & & 225 & 87 & 469 \\
\hline Palms & & 5 & & & \\
\hline Bananas & & & & & 75 \\
\hline Other trees & 550 & 183 & & & 25 \\
\hline Total & $1048^{a}$ & $563^{b}$ & $556^{b}$ & $307^{b}$ & $1394^{a}$ \\
\hline
\end{tabular}

a,b,c: Different letters along rows indicate significant differences $(p<0.05)$ according to Tukey's test.

Young cocoa agroforestry systems had similar tree density to secondary forests (over 1000 trees per hectare), which was two to four times that of other land uses (Table 3). The young cocoa-based agroforestry had a significantly higher tree density compared with old cocoa-agroforestry and multipurpose tree species agroforestry plots. While a $3 \mathrm{~m} \times 3 \mathrm{~m}$ planting grid yields $1111 \mathrm{stems} \mathrm{ha}^{-1}$, the tree population reduces as trees grow older.

\subsection{Soil Properties}

Converting natural forest to any land use under cocoa agroforestry systems, including multistrata agroforestry in Sulawesi, markedly reduced topsoil (0 to $30 \mathrm{~cm}$ depth) organic matter concentration. In the remnant secondary forest, soil organic carbon concentration at the $0-10 \mathrm{~cm}$ depth was $22 \mathrm{~g} \mathrm{~kg}^{-1}$, categorized as 'high' according to [55] compared with only around $15 \mathrm{~g} \mathrm{~kg}^{-1}$ (moderate) for non-forest systems (Figure 4a). Variations among the agroforestry land uses (non-forest) were relatively small, within a $4 \mathrm{~g} \mathrm{~kg}^{-1}(0.4 \%)$ range, compared to the decline from forest to non-forest.

Surface soil bulk density values (Figure $4 \mathrm{~b}$ ) changed in the opposite direction from the pattern of soil organic matter (Figure 4a). Having the highest C-organic concentration, secondary forest was the least compacted. Consequently, inferred changes in the soil C stock in the top $30 \mathrm{~cm}$ of soil were small.

Converting forest to cocoa agroforestry led to soil compaction and therefore decreased total porosity (data not shown as it is the mirror of bulk density data); multistrata agroforestry mimics the forest condition closest (it is the least compacted).

Increased bulk density (reduced total porosity) resulted in the disappearance of part of the macropores when they are $>60 \mu \mathrm{m}$ (Figure 5a), which consequently reduced the soil's capacity to conduct water (Figure 5b) and affected soil water availability (Figure 5c). The reduction in macro-porosity caused by shifting a forest to CAF resulted in a decreased saturated hydraulic conductivity (Figure 5b). Cocoa farms which were recently converted from forest had the lowest hydraulic conductivity; apparently the hydraulic conductivity improved and became closer to that for 
forest as the land use was transformed to cocoa agroforestry, especially for old cocoa agroforestry and multistrata agroforest.

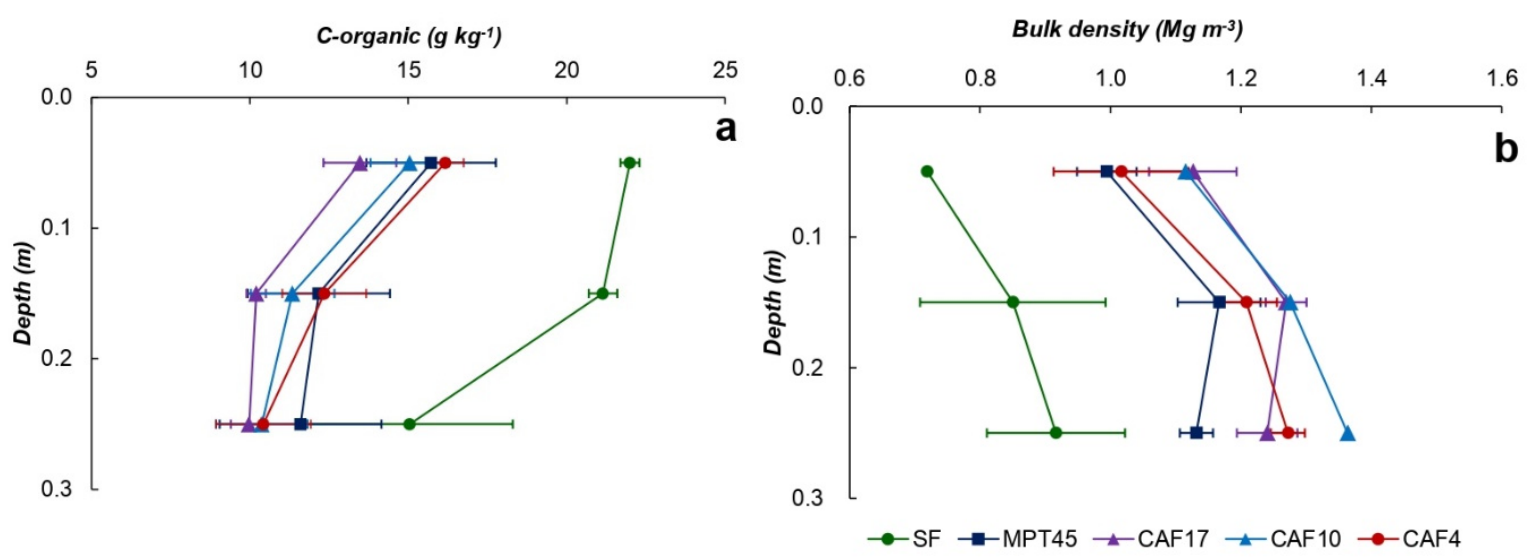

Figure 4. Surface soil (0-30 cm depth) soil organic carbon status (a) and bulk density (b) of secondary tropical forest (SF), multistrata agroforestry that is 45-68 years old (MAF45), cocoa agroforestry that is 17-34 years old (CAF17), cocoa agroforestry that is 10 years old (CAF10), and cocoa agroforestry that is 4-5 years old (CAF4). Bars are standard errors of the means.
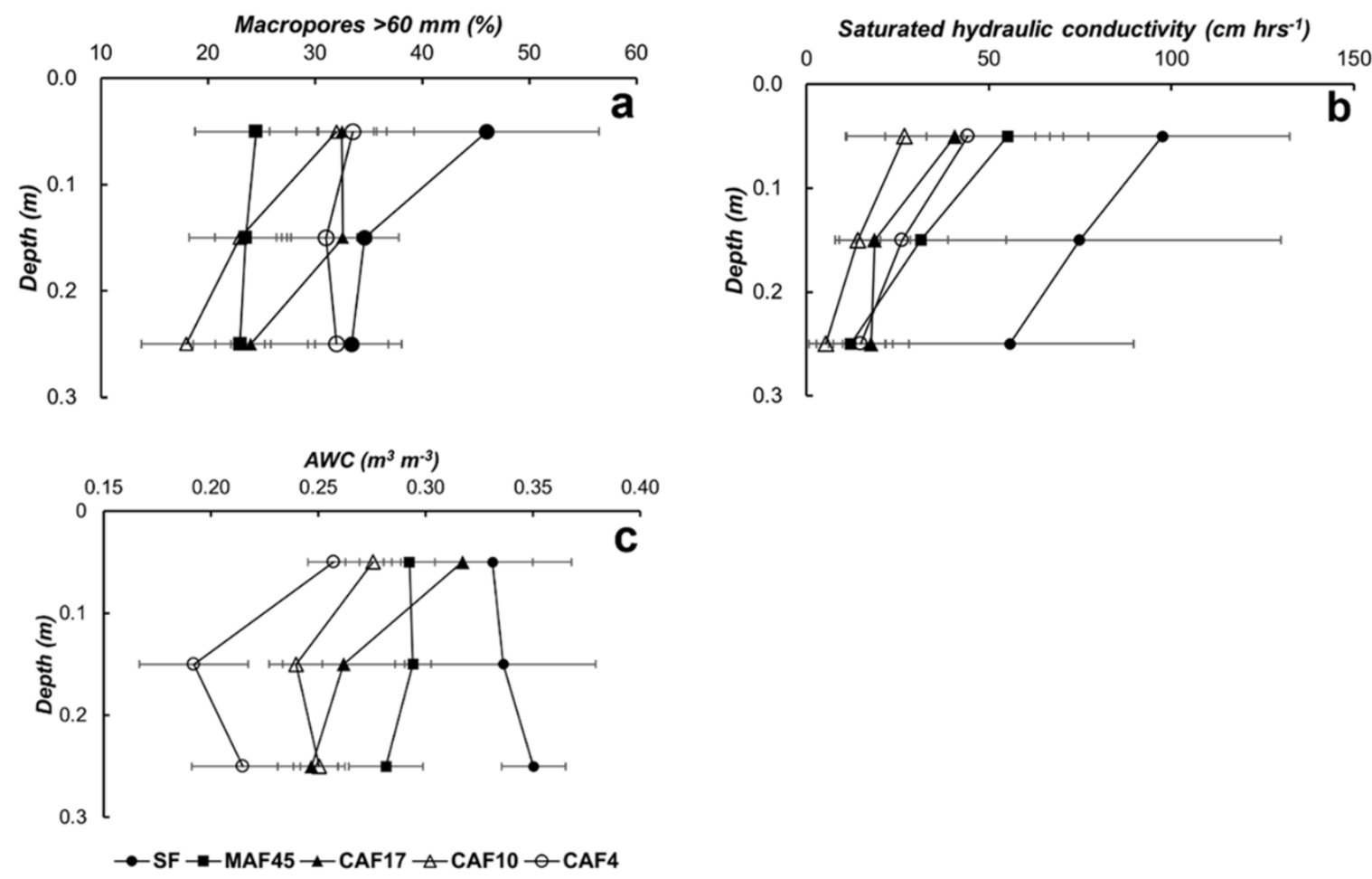

Figure 5. Changes of soil surface (0-30 cm depth) macro-porosity (a), saturated hydraulic conductivity (b) and available water capacity (c), resulted from shifting forest to cocoa farms and its restoration through aging cocoa agroforestry systems that are $4-5$ years old (CAF4), 10-12 years old (CAF10), and 17-34 years old (CAF17), and through multistrata agroforest that is 45-68 years old (MAF45). Bars are standard errors of the means.

Converting forest to other land-uses also led to a change of soil water retention, which specifically reduces the available water capacity, AWC (Figure 5c). Young cocoa agroforestry led to the lowest hydraulic conductivity, but the figure improved closer toward that for forest as the land use was managed using aged cocoa agroforestry and multipurpose tree species. 


\subsection{C-stock}

Converting tropical forest to cocoa-based agroforestry led to a substantial total C-stock decrease, from in total around $320 \mathrm{Mg} \mathrm{ha}^{-1}$ of secondary forest to about 75 to $150 \mathrm{Mg} \mathrm{ha}^{-1}$ of cocoa-based agroforestry (Figure 6). However, C-stock can be restored to approximately half of that found in the forest through aging cocoa agroforestry or practicing long-term multistrata agroforestry farming. While there was a large effect of land-use on the aboveground C-stock, no influence on the soil C-stock was evident (Figure 6), due to the inclusion of a higher soil dry weight in the $0-30 \mathrm{~cm}$ soil layers [9].

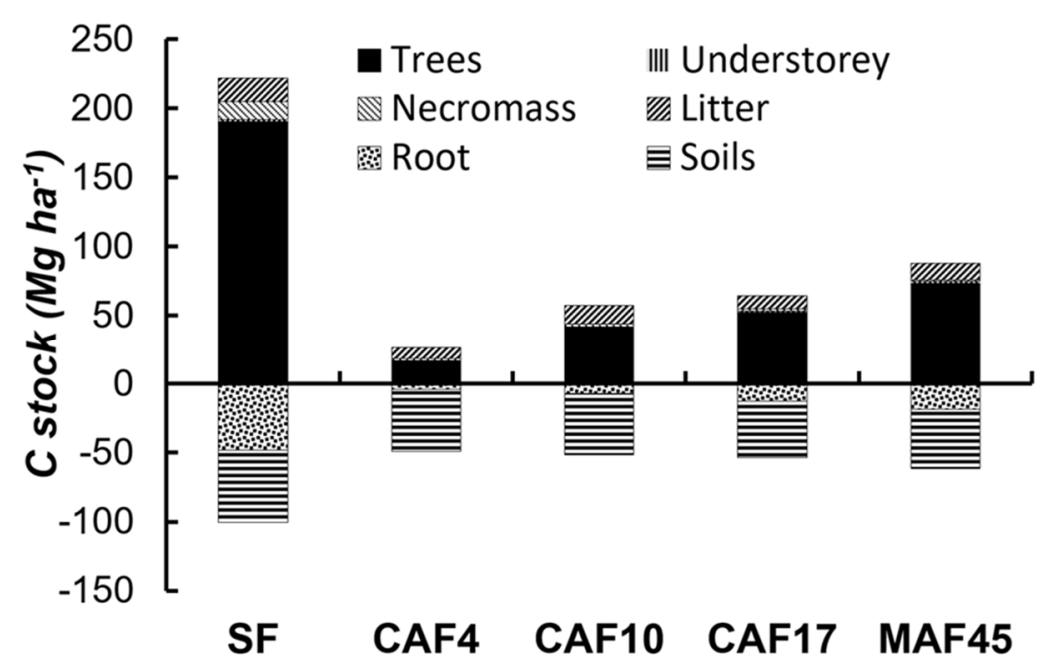

Figure 6. Total above- and below-ground carbon stock of remnant secondary forest (SF) compared with cocoa agroforestry that is $4-5$ years old (CAF4), cocoa agroforestry that is 10-12 years old (CAF10), cocoa agroforestry that is 17-34 years old (CAF17), and multistrata agroforest that is 45-68 years old (MAF45). The figure demonstrates the total C-stock restoration from 4-5 (CAF4) to 17-34 years old cocoa agroforestry (CAF17) and to 45-68 years old multistrata agroforest (MAF45).

\subsection{Available Water Capacity}

Variable soil organic matter concentrations from different CAFs are associated with soil bulk density (Figure 7a), and hence with soil macro-pore reduction (Figure $7 \mathrm{~b}$ ) and soil hydraulic conductivity (Figure 7c). The decline of soil organic matter concentrations was correlated with soil macro-pore collapse and modified pore-size distribution, eventually affecting available water capacity (Figure 7d). Forest, having the highest organic matter concentrations, had the lowest bulk density, and highest macro-porosity, hydraulic conductivity, and plant water availability (Figure 8). 

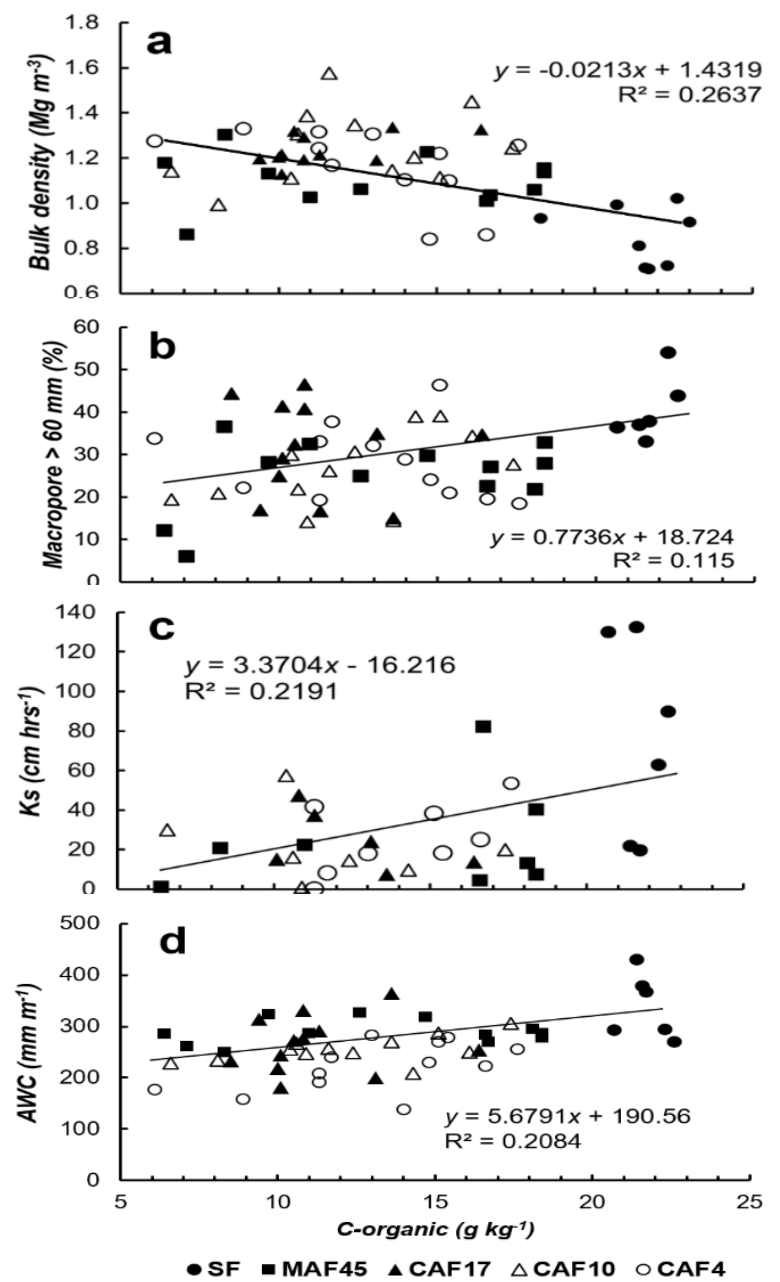

Figure 7. Surface soil bulk density (a), macro-porosity as percentage of total soil pores (b), saturated hydraulic conductivity - Ks (c) and available water capacity - AWC, expressed in mm of water per meter of soil (d) as related to soil organic matter measured at different cocoa-based agroforestry systems, i.e., secondary forest (SF), cocoa agroforestry that is 4-5 years old (CAF4), 10-12 years old (CAF10), and 17-34 years old (CAF17) and multistrata agroforest that is 45-68 years old (MAF45).

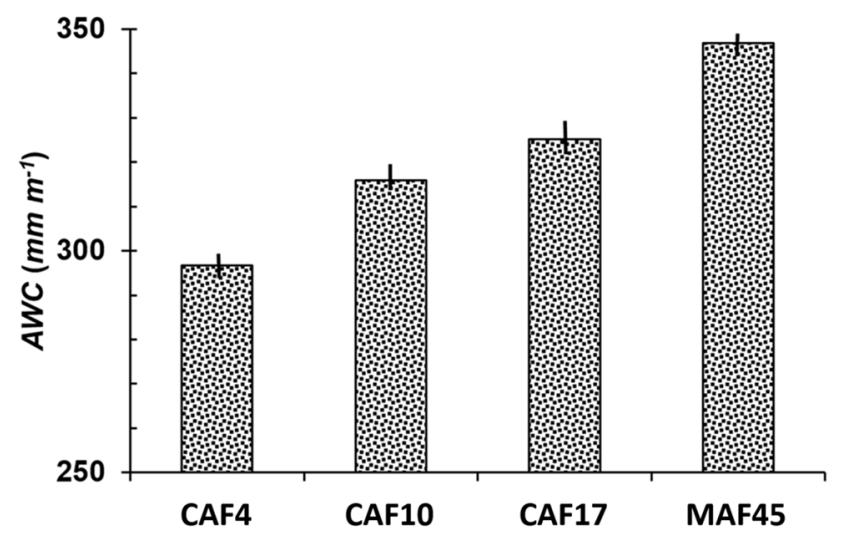

Figure 8. Available water capacity (AWC), expressed as $\mathrm{mm}$ of water per meter of soil of young (4-5 yrs.) cocoa agroforestry (CAF4) compared to aging (17 to 34 yrs.) cocoa-based agroforestry, and old (45-68 yrs.) multistrata agroforest (MAF45). Bars are standard errors of the means. 


\section{Discussion}

Our results provided partial support for the hypothesis that in cacao production systems, the farmer-level benefits of agroforestry through increased water storage, contributing to climate change adaptation, are parallel to global benefits of climate change mitigation through increased $\mathrm{C}$ storage. However, the changes in soil properties are slow and gradual and only a partial recovery towards the conditions found in secondary forest was recorded, even for 45-year old mixed agroforest. This slow belowground change relative to aboveground appearance is in-line with restoration experience elsewhere [56].

Three steps are needed to assert a belowground contribution to climate change adaptation by farmers (Figure 1): A. an increase in soil organic matter content, B. a functional role of changed soil properties in the water balance reducing crop vulnerability to rainfall variability, and C. Deliberate use by farmers to reduce their vulnerability. Our data referred to steps A and B.

In the tradition of 'chronosequence' research where surveys of existing plot-level land cover are interpreted as a pseudo time-sequence, such as we did here, it is not easy, especially for soil properties, to separate cause-effect relations from background variability. While aboveground $C$ stock data clearly differentiate the land cover types (Table 3), with only a partial recovery in older mixed agroforest of the $C$ stocks lost when local forests were converted, soil changes are more subtle. As noted by [9] increased soil bulk density partly conceals reductions in $\mathrm{C}_{\text {org }}$ (expressed per unit dry soil) when carbon stocks in the top $30 \mathrm{~cm}$ of soil are calculated. Thus, specific effects of land cover on $C_{\text {org }}$ and soil $C$ stock are more clearly observed when $C_{\text {org }} / C_{\text {ref }}$ ratios are considered rather than direct $C_{\text {org }}$ observations.

As second step in the argument we similarly obtained clearer evidence when the plot-level $C_{\text {org }}$ parameter, rather than land cover classes, was used as the basis for correlation with other soil parameters. At around $20 \%$ of the variance accounted for (Figure 7), other sources of variation clearly dominate. According to the regression equation of Figure $7 \mathrm{~d}$, increasing soil organic carbon by $1 \mathrm{~g}$ per kilogram of soil ( $0.1 \%$ C-organic improvement) would give an increase of available soil water of about $6 \mathrm{~mm}$ per meter of soil. Our data (Figures 4 and 7) reveal that an increase of $C_{\text {org }}$ of $4 \mathrm{~g} \mathrm{~kg}^{-1}$ $(0.4 \%)$ is feasible when land cover is transformed to the MAF 45 conditions in multistrata agroforestry available plant water, which can be around $9.6 \mathrm{~mm}$ per $0.4 \mathrm{~m}$ of soil (as most of the cocoa roots on these stony soils are concentrated in this layer). An increase of $0.4 \%$ in 45 years from a base of around $2 \%$ corresponds with a soil $\mathrm{C}$ increase of $4 \% \mathrm{y}^{-1}$ that is desirable as part of global climate change policy [57], as the relative increase from 2.0 to 2.4 is $20 \%$ and $1.2^{1 / 45}=1.004$, corresponding with a relative rate of increase of $4 \% \mathrm{y}^{-1}$.

As the average evapotranspiration rate for the humid tropics is $3-4 \mathrm{~mm} \mathrm{day}^{-1}$ [58] and measurements in the dry seasons in Central Sulawesi indicated around $3.6 \mathrm{~mm} \mathrm{day}^{-1}$ [59], this extra available water can support $50 \%$ of cocoa demand for water for any week without any rain in the growing season. In the study area, the average rainfall in the driest months is only $50 \mathrm{~mm}$ [60]. The additional AWC that can be expected with higher soil organic matter content, combines with the reduction of soil evaporation where a permanent litter layer is present [61,62]. Such effects are not dramatic but can at least partly offset increased demand for water by trees with active leaf canopies [63]. However, if shade trees are as shallowly rooted as those in a recent West African case study [64] were, then negative effects on cocoa survival are logical outcomes. Only with deep-rooted trees that have access to deeper soil layers and share up to $1 \mathrm{~mm} \mathrm{day}^{-1}$ to the topsoil by nighttime hydraulic equilibration $[65,66]$ can we expect substantive increases in dry season tolerance in agroforestry systems. A number of the cocoa companion trees may have the deep rooting pattern necessary for such effects, but location-specific observations will be needed to test that [67]. Shade trees in cocoa agroforestry not only improved soil carbon concentrations in Southeast Sulawesi, but also soil structure and aggregation [68], possibly facilitating cocoa root development, in line with our results (Figure 7b) on macroporosity, that will also increase infiltration into the profile and reduction of surface runoff [69]. The water-related functionality of $C_{\text {org }}$ had coefficients of determination of around $20 \%$, suggesting that other factors, such as details of soil structure, play a major role as well. 
What matters to farmers is the overall effects on yield and economic performance of the plots (e.g., in terms of return to labor). Intercropped shade-tree species with cocoa had little or no effects on cocoa yield in earlier studies in Sulawesi $[59,66]$. Elsewhere the distance between shade trees and cocoa was found to be important [70]. Although cocoa yields maybe higher under monocultures system [71,72], returns derived from other agroforestry products compensated the difference in economic terms [73]. Part of the tree diversity on cocoa agroforestry in SE Sulawesi was recently attributed [39] to the fact that they harbor tree species prioritized by male farmers as well as those favored by female farmers. At the interface of aboveground and belowground effects and contributions to both mitigation and adaptation climate change agendas, cocoa agroforestry can indeed be 'climate-smart', contributing to resilience and policy synergy [74]. As detailed in a recent study in Southeast Sulawesi [75], the improvements of cocoa agroforestry relative to cocoa monoculture are modest steps in the direction of physically restoring forest soil conditions.

\section{Conclusions}

In terms of total system, $C$ stock cocoa agroforestry could recover up to half of the stocks of secondary forest in the landscape, while conversion only left $23 \%$ of the original stock, essentially the soil component. Belowground losses after forest conversion but also restoration are slower than the changes aboveground.

Trees in agroforestry are not only relevant for $\mathrm{C}$ storage, but also as provider of farmer income, as modifier of microclimate and in support of soil $C$ storage. In contrast to aboveground $C$ storage, belowground increases in stock have functional relevance. Soil conditions connected to the capacity for CC adaptation, especially minimum soil compaction, greater macro-porosity, and hydraulic conductivity to allow high rain infiltration and higher available water capacity could be directly linked to higher $C_{\text {org }}$ concentrations across the land covers sampled. An increase of $1 \mathrm{~g} \mathrm{~kg}^{-1}(0.1 \%)$ of soil organic carbon increased available soil water capacity by $6 \%$ (vol/vol). Our data confirmed an increase in available water capacity, relevant for survival of week-long dry spells. As such, a contribution can be made to human adaptation to increased rainfall variability.

The water-related functionality of $C_{\text {org }}$ had coefficients of determination of around $20 \%$. Belowground consequences of tree cover in agroforestry are only quantifiable in large data sets but are likely as relevant as the more visible effects aboveground.

Our results confirmed that a shift from cocoa monoculture to forms of agroforestry has benefits for the farmer in terms of an increased soil water buffering and soil structure that, even though modest in effect size, contributes to tolerance of dry season conditions. These systems also contribute, in modest amounts, to increased storage of carbon in aboveground and belowground pools that ought to be reflected in the country's national C accounting system and be included in the Nationally Determined Contributions to the Paris Agreement on combatting global climate change. A shift from a focus on cocoa to be intensively managed as monoculture crop to one that is best grown in mixed agroforestry systems, along with other tree commodities will be appropriate.

Author Contributions: Conceptualization and methodology (S.G., K.H. and M.v.N.); investigation (S.S., R.S., I.H.M., M.N., D.U.); data curation (S.S., K.H., S.G., M.v.N.); writing—original draft preparation (S.G., K.H., M.v.N.); writing-review and editing (S.G., M.v.N.). All authors have read and agreed to the published version of the manuscript.

Funding: We thank Ford Foundation for funding the project (grant number 0155-1534) as an effort to enhance cocoa farmers' business performance in Polman, West Sulawesi.

Acknowledgments: We are grateful to all farmers for fieldwork supports during the research, especially Annas, Sahabuddin, and Abdullah, and their team coordinated through the farmer group. The land clearing photo in Figure 3 was kindly provided by Anas and Abdullah. We also thank Samsuar for preparing the site map. The publication was prepared with the support of Ministry of Research and Technology, High Education, Republic Indonesia through WCU collaborative research scheme between Brawijaya, Hasanuddin, and Sebelas Maret Universities. 
Conflicts of Interest: The authors declare no conflict of interest. The funders had no role in the design of the study; in the collection, analyses, or interpretation of data; in the writing of the manuscript, or in the decision to publish the results.

\section{References}

1. Atangana, A.; Khasa, D.; Chang, S.; Degrande, A. Tropical Agroforestry; Springer Science: London, UK, 2013.

2. Van Noordwijk, M. Sustainable Development through Trees on Farms: Agroforestry in its Fifth Decade; World Agroforestry (ICRAF): Bogor, Indonesia, 2019.

3. Tscharntke, T.; Clough, Y.; Bhagwat, S.A.; Buchori, D.; Faust, H.; Hertel, D.; Hölscher, D.; Juhrbandt, J.; Kessler, M.; Perfecto, I.; et al. Multifunctional shade-tree management in tropical agroforestry landscapes-A review. J. Appl. Ecol. 2011, 48, 619-629. [CrossRef]

4. Duguma, L.A.; Minang, P.A.; Van Noordwijk, M. Climate change mitigation and adaptation in the land use sector: From complementarity to synergy. Environ. Manag. 2014, 54, 420-432. [CrossRef] [PubMed]

5. Harvey, C.A.; Chac, M.; Donatti, C.I.; Garen, E.; Hannah, L.; Andrade, A.; Bede, L.; Brown, D.; Calle, A.; Char, J. Climate-Smart Landscapes: Opportunities and Challenges for Integrating Adaptation and Mitigation in Tropical Agriculture. Conserv. Lett. 2014, 7, 77-90. [CrossRef]

6. $\quad$ Rosenstock, T.S.; Wilkes, A.; Jallo, C.; Namoi, N.; Bulusu, M.; Suber, M.; Mboi, D.; Mulia, R.; Simelton, E.; Richards, M.; et al. Making trees count: Measurement and reporting of agroforestry in UNFCCC national communications of non-Annex I countries. Agric. Ecosyst. Environ. 2019, 284, 106569. [CrossRef]

7. Zomer, R.J.; Neufeldt, H.; Xu, J.; Ahrends, A.; Bossio, D.; Trabucco, A.; Van Noordwijk, M.; Wang, M. Global Tree Cover and Biomass Carbon on Agricultural Land: The contribution of agroforestry to global and national carbon budgets. Sci. Rep. 2016, 6, 29987. [CrossRef]

8. Van Noordwijk, M.; Bayala, J.; Hairiah, K.; Lusiana, B.; Muthuri, C.; Khasanah, N.; Mulia, R. Agroforestry solutions for buffering climate variability and adapting to change. In Climate Change Impact and Adaptation in Agricultural Systems; CAB-International: Wallingford, UK, 2014; pp. 216-232.

9. Hairiah, K.; van Noordwijk, M.; Sasi, R.R.; Dwi, D.; Suprayogo, D.; Kurniawan, S.; Prayogo, C.; Gusli, S. Soil carbon stocks in Indonesian (agro) forest transitions: Compaction conceals lower carbon concentrations in standard accounting. Agric. Ecosyst. Environ. 2020, 294, 106879. [CrossRef]

10. Sanchez, P.A. Properties and Management of Soils in the Tropics; Cambridge University Press: Cambridge, UK, 2019. [CrossRef]

11. Wang, F.; Li, Z.; Ding, Y.; Sayer, E.J.; Li, Q.; Zou, B.; Mo, Q.; Li, Y.; Lu, X.; Tang, J.; et al. Tropical forest restoration: Fast resilience of plant biomass contrasts with slow recovery of stable soil C stocks. Funct. Ecol. 2017, 31, 2344-2355. [CrossRef]

12. Dollinger, J.; Jose, S. Agroforestry for soil health. Agrofor. Syst. 2018, 92, 213-219. [CrossRef]

13. Van Noordwijk, M.; Cerri, C.; Woomer, P.L.; Nugroho, K.; Bernoux, M. Soil carbon dynamics in the humid tropical forest zone. Geoderma 1997, 79, 187-225. [CrossRef]

14. Lusiana, B.; Kuyah, S.; Öborn, I.; van Noordwijk, M. Typology and metrics of ecosystem services and functions as the basis for payments, rewards and co-investment. In Co-Investment in Ecosystem Services: Global Lessons from Payment and Incentive Schemes; Namirembe, S., Leimona, B., van Noordwijk, M., Minang, P., Eds.; World Agroforestry Centre (ICRAF): Nairobi, Kenya, 2017.

15. Van Noordwijk, M.; Martikainen, P.; Bottner, P.; Cuevas, E.; Rouland, C.; Dhillion, S.S. Global change and root function. Glob. Chang. Biol. 1998, 4, 759-772. [CrossRef]

16. Van Noordwijk, M.; Bizard, V.; Wangpakapattanawong, P.; Tata, H.L.; Villamor, G.B.; Leimona, B. Tree cover transitions and food security in Southeast Asia. Glob. Food Secur. 2014, 3, 200-208. [CrossRef]

17. Van Noordwijk, M.; Hoang, M.H.; Neufeldt, H.; Oborn, I.; Yatich, T. How Trees and People Can Co-Adapt to Climate Change: Reducing Vulnerability through Multifunctional Agroforestry Landscapes; World Agroforestry Centre (ICRAF): Nairobi, Kenya, 2011.

18. Dewi, S.; Van Noordwijk, M.; Zulkarnain, M.T.; Dwiputra, A.; Hyman, G.; Prabhu, R.; Gitz, V.; Nasi, R. Tropical forest-transition landscapes: A portfolio for studying people, tree crops and agro-ecological change in context. Int. J. Biodivers. Sci. Ecosyst. Serv. Manag. 2017, 13, 312-329. [CrossRef] 
19. Abdulai, I.; Vaast, P.; Hoffmann, M.P.; Asare, R.; Jassogne, L.; van Asten, P.; Rötter, R.P.; Graefe, S. Cocoa agroforestry is less resilient to sub-optimal and extreme climate than cocoa in full sun: Reply to Norgrove (2017). Glob. Chang. Biol. 2018, 24, e733-e740. [CrossRef] [PubMed]

20. Cerda, R.; Deheuvels, O.; Calvache, D. Contribution of cocoa agroforestry systems to family income and domestic consumption: Looking toward intensification. Agrofor. Syst. 2014, 88, 957-981. [CrossRef]

21. Somarriba, E.; Beer, J. Productivity of Theobroma cacao agroforestry systems with timber or legume service shade trees. Agrofor. Syst. 2011, 81, 109-121. [CrossRef]

22. Vaast, P.; Somarriba, E. Trade-offs between crop intensification and ecosystem services: The role of agroforestry in cocoa cultivation. Agrofor. Syst. 2014, 88, 947-956. [CrossRef]

23. World Atlas. Top 10 Cocoa Producing Countries-WorldAtlas [WWW Document]. Available online: https://www.worldatlas.com/articles/top-10-cocoa-producing-countries (accessed on 13 August 2019).

24. Tromba, A. What Stats Reveal about the Top 10 Cocoa Producing Countries [WWW Document]. ICCO. 2019. Available online: https://foodensity.com/cocoa-producing-countries/ (accessed on 13 August 2019).

25. Kroeger, A.; Koenig, S.; Thomson, A.; Streck, C. Forest- and Climate-Smart Cocoa in Côte d'Ivoire and Ghana, Aligning Stakeholders to Support Smallholders in Deforestation-Free Cocoa; World Bank: Washington, DC, USA, 2017.

26. PDSIP. Outlook Kakao—Komoditas Pertanian Subsektor Perkebunan; Kementerian Pertanian: Jakarta, Indonesia, 2016.

27. Ruf, F. The Sulawesi case: Deforestation, pre-cocoa and cocoa migrations. In Beyond tropical Deforestation: From Tropical Deforestation to Forest Cover Dynamics and Forest Development; Babin, D., Ed.; CIRAD: Montpellier, France, 2004; pp. 277-298.

28. Hartmann, M.; Niklaus, P.A.; Zimmermann, S.; Schmutz, S.; Kremer, J.; Abarenkov, K.; Lu, P. Resistance and resilience of the forest soil microbiome to logging-associated compaction. ISME J. 2013, 8, 226-244. [CrossRef]

29. Udawatta, R.P.; Rankoth, L.M.; Jose, S. Agroforestry and Biodiversity. Sustainability 2019, 11, 2879. [CrossRef]

30. Gijsman, A.J. Deforestation and Land Use: Changes in Physical and Biological Soil Properties in Relation to Sustainability; Agricultural University Wageningen, Department of Soil Science and Geology: Wageningen, The Netherlands, 1992.

31. Wang, Q.; Wang, S.; Yu, X. Decline of soil fertility during forest conversion of secondary forest to chinese fir plantations in subtropical China. Land Degrad. Dev. 2011, 22, 444-452. [CrossRef]

32. Mortimer, R.; Saj, S.; David, C. Supporting and regulating ecosystem services in cacao agroforestry systems. Agrofor. Syst. 2018, 6, 1639-1657. [CrossRef]

33. Rousseau, G.X.; Deheuvels, O.; Arias, I.R.; Somarriba, E. Indicating soil quality in cacao-based agroforestry systems and old-growth forests: The potential of soil macrofauna assemblage. Ecol. Indic. 2012, 23, 535-543. [CrossRef]

34. Fearnside, P.M. Global Warming and Tropical Land-Use Change: Greenhouse Gas Emission from Biomass Burning, Decomposition and Soils in Forest Conversion, Shifting Cultivation and Secondary Vegetation. Clim. Chang. 2000, 46, 115-158. [CrossRef]

35. Van Noordwijk, M.; Rahayu, S.; Hairiah, K.; Wulan, Y.C.; Farida, A.; Verbist, B. Carbon stock assessment for a forest-to-coffee conversion landscape in Sumber-Jaya (Lampung, Indonesia): From allometric equations to land use change analysis. Sci. China Ser. C 2002, 45, 75-86.

36. Schneider, B.M.; Andres, C.; Trujillo, G.; Alcon, F.; Amurrio, P.; Perez, E.; Weibel, F.; Milz, J. Cocoa and total system yields of organic and conventional agroforestry vs. monoculture systems in a long-term field trial in Bolivia. Expl. Agric. 2016, 53, 1-24. [CrossRef]

37. Guest, D.; Keane, P. Vascular-Streak Dieback: A New Encounter Disease of Cacao in Papua New Guinea and Southeast Asia Caused by the Obligate Basidiomycete Oncobasidium theobromae. Phytopathology 2007, 97, 1654-1657. [CrossRef]

38. Sari, R.R.; Saputra, D.D.; Hairiah, K.; Rozendaal, D.M.A.; Roshetko, J.; van Noordwijk, M. Gendered species preferences link tree diversity and carbon stocks in cacao agroforest in Southeast Sulawesi, Indonesia. Land 2020, 9, 108. [CrossRef]

39. Hairiah, K.; Dewi, S.; Agus, F.; Velarde, S.; Ekadinata, A.; Rahayu, S.; van Noordwijk, M. Measuring Carbon Stocks: Across Land Use Systems: A Manual; World Agroforestry Centre (ICRAF): Bogor, Indonesia, 2011. 
40. Chave, J.; Andalo, C.; Brown, S.; Cairns, M.A.; Chambers, J.Q.; Eamus, D.; Fölster, H.; Fromard, F.; Higuchi, N.; Kira, T.; et al. Tree allometry and improved estimation of carbon stocks and balance in tropical forests. Oecologia 2005, 145, 87-99. [CrossRef]

41. Yuliasmara, F.; Wibawa, A.; Prawoto, A. Carbon stock in different ages and plantation systemof cocoa: Allometric approach. Pelita Perkeb. Coffee Cocoa Res. J. 2009, 25, 132. [CrossRef]

42. Arifin, J. Estimasi Penyimpanan C Pada Berbagai Sistem Penggunaan Lahan di Kecamatan Ngantang; Universitas Brawijaya: Malang, Indonesia, 2001.

43. Brown, S. Estimating Biomass and Biomass Change of Tropical Forests: A Primer; Food and Agriclture Organization: Rome, Italy, 1997.

44. Mokany, K.; Raison, R.J.; Prokushkin, A.S. Critical analysis of root: Shoot ratios in terrestrial biomes. Glob. Chang. Biol. 2006, 12, 84-96. [CrossRef]

45. Norgrove, L.; Hauser, S. Carbon stocks in shaded Theobroma cacao farms and adjacent secondary forests of similar age in Cameroon. Trop. Ecol. 2013, 54, 15-23.

46. Naelson, D.W.; Sommers, L.E. Carbon and Organic Matter. In Methods of Soil Analysis, Part 3, Chemical Methods; Page, A.L., Baker, D.E., Keeney, D.R., Eds.; American Society of Agronomy: Madison, WI, USA, 1996; pp. 1004-1005.

47. Blake, G.R.; Hartge, K.H. Bulk density. In Methods of Soil Analysis: Part 1-Physical and Mineralogical Methods; Klute, A., Ed.; Soil Science Society of America, American Society of Agronomy: Madison, WI, USA, 1986; pp. 363-375.

48. Gee, G.W.; Or, D. 2.4 Particle-size analysis. In Methods of Soil Analysis: Part 4 Physical Methods; Klute, A., Ed.; Soil Science Society of America, American Society of Agronomy: Madison, WI, USA, 2002; pp. $255-293$.

49. Klute, A.; Dirksen, C. Hydraulic conductivity and diffusivity: Laboratory methods. In Methods of Soil Analysis: Part 1-Physical and Mineralogical Methods; Klute, A., Ed.; Soil Science Society of America, American Society of Agronomy: Madison, WI, USA, 1986; pp. 687-734.

50. Klute, A. Water retention: Laboratory methods. In Methods of Soil Analysis: Part 1-Physical and Mineralogical Methods; Klute, A., Ed.; Soil Science Society of America, American Society of Agronomy: Madison, WI, USA, 1986; pp. 635-662.

51. McIntyre, D.S. Sample preparation. In Methods for Analysis of Irrigated Soils; Loveday, J., Ed.; Commonwealth Agricultural Bureaux, Famham Royal: Bucks, UK, 1974; pp. 21-37.

52. Weil, R.; Brady, N. The Nature and Properties of Soils, 15th ed.; Prentice Hall: Upper Saddle River, NJ, USA, 2017.

53. Marshall, T.J.; Holmes, J.W. Soil Physics, 2nd ed.; Cambridge University Press: Cambridge, UK, 1988.

54. Cassel, D.K.; Nielsen, D.R. Field capacity and available water capacity. In Methods of Soil Analysis: Part 1-Physical and Mineralogical Methods; Klute, A., Ed.; Soil Science Society of America, American Society of Agronomy: Madison, WI, USA, 1986; pp. 901-926.

55. Ghaley, B.B.; Wösten, H.; Olesen, J.E.; Schelde, K.; Baby, S.; Karki, Y.K.; Børgesen, C.D.; Smith, P.; Yeluripati, J.; Ferrise, R.; et al. Simulation of Soil Organic Carbon Effects on Long-Term Winter Wheat (Triticum aestivum) Production Under Varying Fertilizer Inputs. Front. Plant Sci. 2018, 9, 1158. [CrossRef]

56. Van Noordwijk, M.; Gitz, V.; Minang, P.A.; Dewi, S.; Leimona, B.; Duguma, L.; Pingault, N.; Meybeck, A. People-Centric Nature-Based Land Restoration through Agroforestry: A Typology. Land 2020, 9, 251. [CrossRef]

57. Minasny, B.; Malone, B.P.; McBratney, A.B.; Angers, D.A.; Arrouays, D.; Chambers, A.; Chaplot, V.; Chen, Z.S.; Cheng, K.; Das, B.S.; et al. Soil carbon 4 per mille. Geoderma 2017, 292, 59-86. [CrossRef]

58. Juarez, R.I.N.; Hodnett, M.G.; Fu, R.; Goulden, M.L.; Randow, C. Control of Dry Season Evapotranspiration over the Amazonian Forest as Inferred from Observations at a Southern Amazon Forest Site. J. Clim. 2007, 20, 2827-2838. [CrossRef]

59. Olchev, A.; Ibrom, A.; Erasmi, S. Effects of land-use changes on evapotranspiration of tropical rain forest margin area in Central Sulawesi (Indonesia): Modelling study with a regional SVAT model. Ecol. Model. 2008, 212, 131-137. [CrossRef]

60. BPS Polman. Kabupaten Polewali Mandar dalam Angka (Polewali Mandar Regency in Figures; PEMDA Polman: Polewali, Indonesia, 2017.

61. Niether, W.; Schneidewind, U.; Armengot, L.; Adamtey, N.; Schneider, M.; Gerold, G. Spatial-temporal soil moisture dynamics under different cocoa production systems. Catena 2017, 158, 340-349. [CrossRef] 
62. Jackson, N.A.; Wallace, J.S. Soil evaporation measurements in an agroforestry system in Kenya. Agric. For. Meteorol. 1999, 94, 203-215. [CrossRef]

63. Lin, B.B. Agroforestry management as an adaptive strategy against potential microclimate extremes in coffee agriculture. Agric. For. Meteorol. 2007, 144, 85-94. [CrossRef]

64. Abdulai, I.; Jassogne, L.; Graefe, S.; Asare, R.; Asten, P.; Van Vaast, P.; La, P. Characterization of cocoa production, income diversification and shade tree management along a climate gradient in Ghana. PLoS ONE 2018, 13, e0195777. [CrossRef] [PubMed]

65. Bayala, J.; Heng, L.K.; van Noordwijk, M.; Ouedraogo, S.J. Hydraulic redistribution study in two native tree species of agroforestry parklands of West African dry savanna. Acta Oecol. 2008, 34, 370-378. [CrossRef]

66. Van Noordwijk, M.; Lawson, G.; Hairiah, K.; Wilson, J. Root distribution of trees and crops: Competition and/or complementarity. In Tree-Crop Interactions: Agroforestry in a Changing Climate; Ong, C.K., Black, C.R., Wilson, J., Eds.; CAB International: Wallingford, UK, 2015; pp. 221-257. [CrossRef]

67. Hairiah, K.; Widianto, W.; Suprayogo, D.; van Noordwijk, M. Tree Roots Anchoring and Binding Soil: Reducing Landslide Risk in Indonesian Agroforestry. Land 2020, 9, 256. [CrossRef]

68. Wartenberg, A.C.; Blaser, W.J.; Roshetko, J.M.; van Noordwijk, M.; Six, J. Soil fertility and Theobroma cacao growth and productivity under commonly intercropped shade-tree species in Sulawesi, Indonesia. Plant Soil 2019. [CrossRef]

69. Suprayogo, D.; van Noordwijk, M.; Hairiah, K.; Meilasari, N.; Rabbani, A.L.; Ishaq, R.M.; Widianto, W. Infiltration-Friendly Agroforestry Land Uses on Volcanic Slopes in the Rejoso Watershed, East Java, Indonesia. Land 2020, 9, 240. [CrossRef]

70. Koko, L.K.; Snoeck, D.; Lekadou, T.T.; Assiri, A.A. Cacao-fruit tree intercropping effects on cocoa yield, plant vigour and light interception in Côte d'Ivoire. Agrofor. Syst. 2013, 87, 1043-1052. [CrossRef]

71. Armengot, L.; Barbieri, P.; Andres, C.; Milz, J.; Schneider, M. Cacao agroforestry systems have higher return on labor compared to full-sun monocultures. Agron. Sustain. Dev. 2016, 36. [CrossRef]

72. Niether, W.; Schneidewind, U.; Fuchs, M.; Schneider, M.; Armengot, L. Below- and aboveground production in cocoa monocultures and agroforestry systems. Sci. Total Environ. 2019, 657, 558-567. [CrossRef] [PubMed]

73. Somarriba, E.; Cerda, R.; Orozco, L.; Cifuentes, M.; Dávila, H.; Espin, T.; Mavisoy, H.; Ávila, G.; Alvarado, E.; Poveda, V.; et al. Carbon stocks and cocoa yields in agroforestry systems of Central America. Agric. Ecosyst. Environ. 2013, 173, 46-57. [CrossRef]

74. Van Noordwijk, M. Agroforestry as nexus of sustainable development goals. IOP Conf. Ser. Earth Environ. Sci. 2020, 449, 012001. [CrossRef]

75. Saputra, D.D.; Sari, R.R.; Hairiah, K.; Roshetko, J.; Suprayogo, D.; van Noordwijk, M. Can cocoa agroforestry restore degraded soil structure following conversion from forest to agricultural use? Agrofor. Syst. 2020, in press.

(C) 2020 by the authors. Licensee MDPI, Basel, Switzerland. This article is an open access article distributed under the terms and conditions of the Creative Commons Attribution (CC BY) license (http://creativecommons.org/licenses/by/4.0/). 